Meta

Journal des traducteurs

Translators' Journal

\title{
Towards a Naive Characterization of Translation
}

\section{Probal Dasgupta}

Volume 40, numéro 3, septembre 1995

La traduction, qu'est-ce à dire? Phénoménologies de la traduction

URI : https://id.erudit.org/iderudit/002485ar

DOI : https://doi.org/10.7202/002485ar

Aller au sommaire du numéro

Éditeur(s)

Les Presses de l'Université de Montréal

ISSN

0026-0452 (imprimé)

1492-1421 (numérique)

Découvrir la revue

Citer cet article

Dasgupta, P. (1995). Towards a Naive Characterization of Translation. Meta, 40(3), 356-358. https://doi.org/10.7202/002485ar

\section{Résumé de l'article}

L'auteur réexamine la définition habituelle de la traduction comme transfert sémantique en posant un regard critique sur la théorie même de la signification (meaning) à travers trois problématiques. Le discours scientifique prétendant exercer une rationalité supérieure débouche sur l'impasse de la spécialisation. Le discours logique se heurte à la difficulté de trouver un système de principes de signification satisfaisant pour l'ensemble des usages linguistiques. Ce qui mène à la dernière problématique : la négociation rendue impossible, faute de base logique commune, entre les discours scientifiques et les discours empiriques. 


\title{
TOWARDS A NAIVE CHARACTERIZATION OF TRANSLATION
}

Probal. Dasgil/pta

University of thiderahod. Huderabad. Indica

\begin{abstract}
Résumé
L'auteur réexamine la définision habituelle de la traduction comme transfert sémantique en posant un regard critique sur la thérrie même de la signification (meaning) à travers trois problematique's. La discours scicntifique préfendant evercer une rationalité supérieure débouche sur l'impasse de la spécialisation. Lé discours logique se helurté a la difficulté de trower un système de principes de signification satisfaisant pour l'ensemble de's

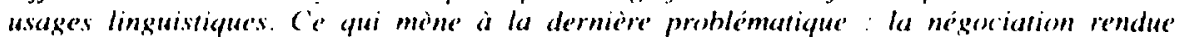
impossible. faute de base logique commune. contre les discours scientifique's at les disconors empiriques.
\end{abstract}

Producing a naive answer to the question "What is translating?" is less easy than one might wish. One's first draft goes like this: if a text can be translated, one assumes that the text means something and that this something reappears in the target language version. This apparently straightforward account relativizes the activity of translation to the existence of meaning. Can we keep faith with this idea of what counts as ordinary thinking about translation? Can the entreprise of translation studies rest on the assumption that semantic study or some other mode of analysis of natural language meanings can in principle become explicit? Will such explicitness really help us to make sense of the activity of translating? Such questions arise immediately, and it becomes difficult to hold on to such a first draft as a really naive answer.

Hence the present article. We take it that there are some serious challenges that any theory of "meaning" must face, and we offer a particular story of how these challenges appear. It is unclear if anybody"s initial faith in the possibility of a semantics survives the challenges outlined here. If there cannot he any coherent field of semantics, then no systematic body of cumulative knowledge can grow in the field of translation studies. For there will be no conceptual architecture to support such a hody. We are then left with a ground, cleared to the extent that we stop hoping for a theoretical edifice that will save us the trouble of standing on that ground, and perhaps it becomes possible for us, in $\%$ en fashion, to repeat the first draft and discover that it is, after all, an acceptable naive answer to the question. properly intoned by a person who has made the theoretical journey and tasted its dead ends.

We turn now to the theoretical trip. Let us focus on issues and not on hibliographical or historical paraphernalia. It may help if we call our problems the Science Problem, the Logic Problem, and the Negotiation Problem, arising in that order.

The Science Problem has to do with the fact that ordinary people disown the implications of their own speech and delegate their meaning powers to the scientists. Thus, we speak of the sun rising and setting, but in a self-effacing gesture we tell each other that it is the earth that goes around the sun and produces the illusion of the sun rising and setting.

From this it follows - and this is the Science Problem for a semantic theory -. that ordinary speakers, in their standard delegation of power to the sciences, are disqualifying themselves as witness on whose data a semantic account of language can be based. Speakers are telling each other, and therefore us as semanticists as well, that speakers as

Meta. XI., 3. 1995 
speakers have no authority to tell any true stories about meaning, but must defer to the superior authority of specialists. Therefore a semantic account of ordinary language cannot be founded on the confident intuitive judgments of native speakers. Their judgments. when they exist, are surrounded by giggles, hedges, and references to the superior rationality of specialists.

One response to the Science Problem might be to tum to the scientists for the guidance not available from the native speaker. In practice, this response tums out to be not so much a failure as an expensive washout. In theory, such a response is doomed to failure for reasons of principle, since each individual science makes a sharp distinction between its little domain of cultivation and the rest of the cosmos as a zone of barbaric, unculturable nature. Given this limited attention bubble within which each special discipline sustains its illusion of total intelligibility, no semanticist can rationally cross the boundary between what a given discipline treats as systematizable and what it is forced to dismiss as undescribed nature (or nature undescribed in terms that intelligibly interact with the terms of that discipline). By the same token, one cannot seriously bridge the gaps between disciplines. In other words, there is no science, there are only sciences which fail to add up.

A second response to the Science Problem is to re-empower the ordinary speaker of a language, to relativize the sciences to the matrix language as a whole. Since real speakers empirically refuse to accept responsibility, one has to make do with a thought experiment with brave speaker-figures trying out such an adventure.

In this experiment, our brave speaker faces the Logic Problem, which involves asking what set of principles, without referring to particular sciences, can reflect our concept-forming capacities so generally that they can sponsor meaning-arrangements for ordinary and specialized language use. The difficulty is that there are two opposite ways such an inquiry can proceed, and we have no rational basis for choosing one rather than the other.

One way is to mimic various sciences and try to resolve complex entities and processes into simpler components that can be systematized on a domain by domain basis. The other way is to seek a common core of basic notions across the board (notions that seem easy to children, that correspond to basic words in the sense of glottochronological research, etc.) and then to get back to the Science Problem. The Logic Problem lies in the fact that there is no principled method of choosing between these two procedures. The first way leads to simple primes like Vertical, Temperature, etc., while the second way leads to easy words like Sky, Fire, etc., and the two languages fails to meet, as you can verify.

So the Science Problem leads to the Logic Problem for which no formal solution exists. Could one conceivably try for a negotiated settlement, seeing that nothing works in the court of law? This brings us to the Negotiation Problem: who will negotiate with whom and in what language, to attain what settled semantic system? This formulation starts from the premise that people negotiate to further their interests, and points towards a final settlement in the form of a semantic system of traffic that might work to everybody's advantage at some optimal level.

To the extent that there is going to be negotiation, even in a thought experiment, one must of course re-raise the question of which type of logic makes such a negotiation tick - an interscientific logic of simple primes or a pretheoretical logic of basic easies. If the question is to be answered by saying "Both," then we need workable equations mapping between the easy world of a dialogue and the simple cosmos of a science textbook. That brings us back to the Logic Problem which we thought we found insoluble. 
Perhaps the right answer is that the negotiation itself will keep fashioning an appropriate logic as it proceeds? Such a move pushes us towards the deeper question of the conditions shaping the very possibilities of a negotiated semantics. If the self-interest perceptions of the real or presumed actors do not lead to a sense of need for negotiation, then either there will not be any negotiation, in principle, or there will be a limited and instrumental exercise of negotiation without any implication of the negotiated settlements being accepted as valid or rational. In such a scenario, even a thought-experiment will presume that only some semantic subcultures may wish to open their doors. It is they who will negotiate with some other subcultures over the possibility of attaining a sense of valid communicability extending over more than one subculture. Opacity will then be an integral part of the picture. For there are going to be certain other subcultures that refuse to play ball. Then the game cannot be universal. And nothing really makes sense.

Does the Zen master, then, repeat paragraph one, implying that there is a naive meaning. after all, despite theoretical aporias, because people continue to produce and accept translations - and even to edit them. suggesting that translations can be improved? Have we cleared the ground on which one must stand to be able to broach these questions clearly? 